merely by his inventiveness, but also by his independence of fashions in astronomical thought, by the admirable conservatism he always showed in interpreting his observations, and by the high quality of everything he did. In an epoch during which astronomy has become dominated by huge telescopes, he managed to make contributions of the finest and most significant character by his mastery of the ideas of classical optics, using only small telescopes and comparatively simple apparatus.

Lyot was awarded the Gold Medal of the Royal Astronomical Society in 1939, and the Bruce Medal of the Astronomical Society of the Pacific in 1947. $\mathrm{He}$ is survived by a widow and two sons.

$$
\text { R. O. REDMAN }
$$

\section{Dr. J. F. Cameron}

Jofin Forbes Cameron, Tice-Chancellor of the University of Cambridge during 1933-35 and Master of Gonville and Caius College during 1928-48, died on March 21 at the age of seventy-eight. He was educated at Perth Academy and the University of Edinburgh before going up to Caius in 1895 . In the Mathematical Tripos of 1898 he was Second Wrangler, bracketed with the late Sir James Jeans; and in 1900 he was awarded a Smith's Prize.

Finding that his interests and tastes lay in teaching and administration rather than in original work in mathematics, Cameron devoted his great abilities to these aspects of College and University life, with remarkable success. He had been elected a Fellow of his College in 1899, and in 1900 a lecturer in mathematics. In 1909 he became a tutor and, on his return from important posts in the Ministries of Munitions and Labour during the First World War, sanior tutor. Two years later, in 1921, he was appointed bursar. On the death of Sir Hugh Anderson he was elected to succeed him as Master, in which office he governed his College for twenty years; for when, in 1943, he reached the normal retiring age, the College extended his tenure to the maximum permitted by the statutes - to 1948 , in which year he reached the age of seventy-five.

Cameron's services to the University of Cambridge were manifold and distinguished. Immediately following his graduation he took a lively interest in the small but growing Department of Engineering, and he played an active part in the development of engineering in the University, being chairman of the Faculty Board for some years. He was elected to the Council of the Senate in 1924 and continued to serve on it for many years. He served also on the Financial Roard and on the General Board of the Faculties. He was chairman of the Buildings Syndicate and, for twenty years, chairman of the University Press Syndicate. Cameron also took an active part in civic affairs. He was a town councillor for some years and he was chairman of the Cambridge Gas Company. In College, in the University, and in the town, Cameron's advice and help were often sought and always freely given. His mind was powerful and clear, his approach to problems of any kind was objective, and his judgment sound; and his sincerity and fairness were beyond question. When he retired in 1948 the University paid him the rare honour of conferring upon him an honorary degree of LI.D.; the Orator saluted him as virum ingeniosum, sagacem, strenuum, amicum firmum et constantem-a concise and apt description.
He married Miss Elfrida Sturge, daughter of John Edmond Sturge, of Birmingham and Montserrat, who survives him with one son and one daughter. A younger son died as a prisoner of war after being captured in France.

J. Chadwick

\section{Dr. R. W. Dodgson, O.B.E.}

BORN in 1870 in Wigton, Cumberland, of Quaker parentage, Robert William Dodgson went to Owens College, Manchester, and thence in 1890 entered St. Mary's Hospital, Paddington, as a senior scholar in natural science. There he became assistant pathologist and showed outstanding ability as a teacher as well as in his other duties, his time at St. Mary's being rounded-off by a gold medal award with his. M.D.(London) in 1898.

Dodgson's subsequent career falls into two periods, the first of which was mostly spent abroad. In 1900 he went to South Africa to inquire into the results of anti-typhoid inoculation of British troops serving there. This War Office appointment was followed by the directorship of the Government Research Laboratory at Cape Town under the Plague Administration, and in 1902 he became director of the Pasteur Institute of Rhodesia at Bulawayo. Two years later he returned to Britain and remained in private work until 1911. He then joined Sir Almroth Wright in an investigation of epidemic pneumonia among employees in the gold mines of the Witwatersrand, but in 1913 he left South Africa after a somewhat severe illness. Dodgson visited laboratories in France and Germany on his way home, and reached England just before the outbreak of the First World War.

The second period began in 1915 with an appoint ment under the Ministry of Agriculture and Fisheries to devise a method of freeing mussels from dangerous pollution. Dodgson's approach to this problem was through a comprehensive study of the physiology of the mussel, coupled with bacteriological investigation. A brilliant piece of research was the result, and his solution was applied on a commercial scale at Conway in 1916. Described in his report on mussel purification (1928), it will long be associated with Dodgson's name. The method he devised depends on the natural functioning of the shellfish in large tanks of sea water free from the irritating effects of sterilizing agents. ihe advantages of this principle have now been recognized in the United States, where for many years the exposure of oysters to an initial dose of active chlorine in sea water had been the practice for the purpose of purification. Later, Dodgson was appointed director of the Ministry's Shellfish Services. His study of shellfish problems as a whole led to comprehensive recommendations for compulsory treatment of all molluses destined for human consumption in Great Britain. Although fulfilment of his ideal has not become practicable, his method of purification has been applied at some other shellfish centres in Fritain and abroad. When a chance occurrence directed his attention to the possibility of using mussel purification installations for oyster culture during the off-season, he initiated a series of experiments which have yielded results of much value.

Before his retirement in 1937, which was followed by two years of service as a consultant in shellfish matters, Dodgson's services were recognized by the award of the O.B.E. He died on March 4 at his home in Conway, a bachelor, after a gradual decline in health. 
Dodgson was endowed with sound judgment, singleness of purpose and a capacity for mastering details as well as the broad aspects of the matters which required his attention. H. P. SHenwood

\section{Dr. Poul Jespersen}

THE death of Dr. Poul Jespersen, on December 20, 1951, has removed from the ranks of marine biologists one who shared with Dr. Johs. Schmidt in the pioneer investigations on the life-history of the eel. Born on March 18, 1891, at Naesbyhoved near Odense, Jespersen was a naturalist from his boyhood days. While still a student at the University of Copenhagen, he sailed in 1913 on the schooner Margrethe to search for the larvæ of the eel in the Sargasso Sea. Afterwards, he was to take part in many oceanographic voyages, including the two-year cruise of Dana $I I$ to the Atlantic and the Pacific, and her world circumnavigation during 1928-30. Jespersen published many works on the life-histories of fishes and the importance of plankton as their food; he was also a copepod systematist. He succeeded Ove Paulsen as director of the plankton laboratory of the Danish Commission for Fisheries Research.

His special hobby since youth had been the study of birds, on which he published a number of papers, and in 1941 he became president of the Danish Ornithological Society. Just before his death, Jespersen had been appointed Secretary-General of the International Council for the Exploration of the Sea, and his presence will be missed by many friends at the Council's meetings. His wife and daughter survive him.

F. S. RUSSELL

\section{We regret to announce the following deaths:}

Dr. Maria Montessori, the well-known educationist, on May 6, aged eighty,-one.

Mr. James L. Peters, of the Museum of Comparative Zoology, Cambridge, Mass., known for his "Check list of Birds of the World", aged sixty-two.

\section{NEWS and VIEWS}

Vice-Chancellorship of the University of Birmingham : Sir Raymond Priestley

Sir Raymond Priestley retires on September 30 from the vice-chancellorship of the University of Birmingham, which he has held since 1938. His training as a geologist, his work in the Antarctic with the Shackleton and Scott expeditions, his long service as secretary of the Board of Research Studies at Cambridge and his period as vice-chancellor in Melbourne had given him wide experience of science and its organization, and so it was natural that the Faculty of Science in Birmingham should have skilful and sympathetic support from him; but the other Faculties have had it no less. Dr. Priestley, as he then was, set up his office in the old buildings in the centre of Birmingham, and it was his ambition to take the Faculties of Arts and Law from these buildings to join the rest of the University at Edgbaston. War and scarcities have prevented this ; but many of his other ambitions have been fulfilled. The University has not only doubled its size: its internal government has become more democratic, new departments have been founded (genetics and electron physics are examples on the science side), and new links, such as the Shakespeare Institute at Stratford-on-Avon and the Department of Engineering Production, have been made with the cultural and industrial life of the Midlands.

Sir Raymond has done much for individuals and non-academic organizations in the University; he has always kept in personal touch with students and has been rewarded by enterprising and conscientious work by the officers of the Guild of Undergraduates in successive years. Popular with all the staff, he has shown particular interest in the lower grades and has been a staunch champion of their interests. His educational work has by no means been confined to his own University; he took a large part, for example, in the founding of the University College of the West Indies, and visits to it have been his chief relaxation in recent years. At the request of the University Council, Sir Raymond has remained in office beyond the normal age of retirement, and there will be general regret that he feels unable to continue still longer. He has been, by general consent, one of the outstanding vice-chancellors of his time.

\section{Chemistry at University College, London Prof. H. Terrey}

MaNy friends and students of Mr. Henry Terrey, reader in chemistry at University College, London, since 1937, will have heard with pleasure of his elevation to a chair at that College as from January 1, 1952. He graduated B.Sc. in 1912 and in the same year was appointed student demonstrator in the Chemistry Department, where he has maintained an unbroken service, except for a short period in 1914. As well as having responsibility there for many years for most of the teaching of inorganic chemistry to senior students, he is also lecturer in the chemistry of painters' materials in the Bartlett School of Architecture and has been lecturer in dental metallurgy in University College Hospital Dental School. During the First World War he combined academic duties with research work for the Admiralty. Of researches later carried out with his students the first was an early example of the use of radioactive indicators, in determinations of the hydration of salts. Various X-ray spectrometric studies have been made, for example, of alloys, of silver subfluoride, of indium dichloride and of the coagulation of gold sols. In an examination of the platinoplatinichloride electrode a new and very constant type of chlorine electrode was evolved. Investigations in the chemistry of scandium, samarium and germanium are included among other widely spread work. Interest in history is fruitfully evinced in a paper on Edward 'Turner, the first professor of chemistry at University College. Prof. 'Terrey served on the Council of the Chemical Society during 1928-31. He is chairman of the Board of Examiners for the Internal B.Sc. in chemistry of the University of London, and chairman of a sub-committee on crystallography drawn from the Boards of Chemistry and Physics of the University. 